\title{
Comparison of Nutrient Use Efficiencies and Cost Benefit Ratios in Wine vs. Table Grape Vineyards in Northern Dry Zones of Karnataka, India
}

\author{
Anita E. Kondi*, Prashant C. Tevaratti, Champa B.V. Kulapathi Hipparagi \\ and Shripad Vishweshwar
}

College of Horticulture, Bagalkot - 587 104, Karnataka, India

*Corresponding author

\section{A B S T R A C T}

\section{Keywords}

Table grapes, Wine grapes, Productivity, Nutrient use efficiency, Costbenefit ratio

Article Info

Accepted:

10 February 2019

Available Online:

10 March 2019
Grape is the most commercially valuable crop in India and it is consumed as fresh table grapes and its juice; and processed raisins and its wine. The cultivars of wild and table grapes are evolved over centuries and possess distinct plant phonology, nutrient requirements and finally, the fruit quality. A study was conducted to compare the nutrient use efficiencies in wine and table grapes. Application of three major nutrients was found significantly higher in table grape vineyards in contrast to wine grape orchards. The fresh grape yields of wine and table grapes varied significantly. The wine grape yields were lesser with a mean yield of $12.0 \pm 1.2 \mathrm{t} \mathrm{ha}^{-1}$. In contrast, table grape yields were higher with mean yield $24.0 \pm 1.50 \mathrm{t} \mathrm{ha}^{-1}$. Productivity of grapes per unit of applied $\mathrm{N}, \mathrm{P}$ and $\mathrm{K}$ nutrients were derived using total individual nutrients added and the corresponding yields. It was interesting to observe that the productivity -nutrient ratios of table grapes were found to be significantly higher while, wine grape orchards recorded lower productivitynutrient ratios. The cost-benefit ratios were found to be 1.44 and 1.57 for wine and table grapes respectively.

\section{Introduction}

Grape is the most commercially valuable crop in India and world over. Large volume of fruits is processed into wine while, a significant portion is also consumed as fresh table grapes, dried raisins and processed fresh juice (Yogeeshappa, 2007). The purpose of its consumption/ utilization is determined by the grape fruits and thus, they are broadly categorized into wine and table types. It is documented that the present grapes, belonging to Vitis vinifera sub species vinifera, are originated from the near east (between Iran and Turkey) from its wild progenitor Vitis vinifera sub species sylvestris. There are archeological evidences of wine making in Iran region during the second half of sixth millennium BC (McGovern, 2003). Archeological and genetic studies on grapes indicate that the grape (Vitis vinifera $\mathrm{L}$.) is one of the first domesticated perennials, in the human history and its cultivation dates back to 6000-8000 y ago (Aradhya et al., 2003; Zoe Migicovsky et al., 2017). Dominance of wine cultivars distinctly over table types in the 
Europe, in contrast to dominance of table type in the East Asia over wine cultivars have been attributed to prevailed past religions in the respective regions. As the quality of fruits needed for wine and table are distinctly different, the cultivars are evolved over centuries in accordance with the nutrient management practices (Zoe Migicovsky, 2017). Appreciable levels of differentiation between table and wine grape cultivars as well as fruits have been reported (Aradhya et al., 2003). Thus, the nutrient management practices, soil nutrient contents, grape plant tissues (petioles) and finally, the yields are expected to differ to a great extent. Considering these issues, a study was conducted to compare the nutrient use efficiencies in wine and table grapes cultivated in northern dry zone of Karnataka.

Patrice et al., (2006) reported that "the Catholic church replaced the Romans and enabled spread of grape cultivation to new regions. Crusaders enabled germplasm exchange and spread their religion in northern Europe. The extension of Islam to North Africa and Middle East also had similar significant role in spreading the table grapes".

\section{Materials and Methods}

\section{Study area}

Vijayapur and Bagalkot are the two major grape growing districts of Krishna valley (Figure 1) exists at 500-550m MSL. The region comes under semi-arid climate with low rainfall and high summer temperature associated with cold winter. Thus, the Krishna valley provides ideal conditions for grape cultivation.

\section{Survey of vineyards}

Vineyards of both wine and table grape types were chosen for the study. Information on grape type variety, age soil type, nutrient management practices in terms of major nutrients added (organic and inorganic) and fertigation; organic manures used, amendment by direct soil application etc were collected for each vineyards. The data from vineyards of wine type $(n=20)$ and table type $(n=58)$ were collected separately and general information are furnished in Table 1.

\section{Nutrient additions in vineyards}

The amount of nutrients added in the form of fertilizer through fertigation and direct soil application were derived by considering the quantity and nutrient composition of the fertilizer used. The amounts of organic manures added in each orchard was used to estimate the amounts of nutrients added using per cent nutrient contents of $\mathrm{N}: \mathrm{P}_{2} \mathrm{O}_{5}: \mathrm{K}_{2} \mathrm{O}$ ratios of $1: 0.5: 1$. These values were pooled together to derive the total amounts of individual nutrients added in each vineyard.

\section{Collection and analysis of grape soil}

Representative soil sample were collected from pre selected orchards. From three different points along the row in the orchard (at $45-60 \mathrm{~cm}$ away from the main stem and $45 \mathrm{~cm}$ away from the main row) after harvest of the crop (February-march). Pooled samples were mixed thoroughly and reduced it to half a kilo by quartering technique. The samples were air dried, sieved $(2 \mathrm{~mm})$ and stored in air tight container for analysis. Standard protocols adopted for soil fertility analysis are presented in Table 2. The data obtained were subjected to simple statistical tests using student's t-tests and F-tests were made.

\section{Grape yields and productivity-nutrient ratios}

Some of the grape orchards were visited after the harvest of the crop and the data maintained 
by the grape growers on fresh fruit yields and raisins produced were recorded while, grape yields from other orchards were obtained by contacting them over phone. Finally, the total fresh grape yields were derived for each vineyard. Finally, the productivity of grapes per $\mathrm{kg}$ of individual nutrient were calculated separately by using the formula given below

Productivity - Nutrient Ratio $=\frac{\text { Fresh grape yields (in kgs) }}{\text { Individual nutrient added (in kgs) }}$

\section{Results and Discussion}

\section{Nutrient inputs}

Use of both manures and fertilizers was observed in wine as well as table grape vineyards. However, supplementation of nutrients through fertilizers was substantially higher compared to nutrients from organic manure sources (Figure 2). Among two grape types, application of three major nutrients were found significantly higher in vineyards of table grape types with mean values of 554.1 $\pm 75.4 \mathrm{~kg}-\mathrm{N} \mathrm{ha}{ }^{-1}, 495.2 \pm 73.1 \mathrm{~kg}-\mathrm{P}_{2} \mathrm{O}_{5} \mathrm{ha}^{-1}$ and $807.2 \pm 207.6 \mathrm{~kg}-\mathrm{K}_{2} \mathrm{O} \mathrm{ha}^{-1}$. Contrastingly, the vineyards of wine grapes received significantly lesser amounts of $\mathrm{N}, \mathrm{P}$ and $\mathrm{K}$ with respective quantities of $453.1 \pm 44.7 \mathrm{~kg}$ $\mathrm{N} \mathrm{ha}^{-1}, 427.5 \pm 60.2 \mathrm{~kg}-\mathrm{P}_{2} \mathrm{O}_{5} \mathrm{ha}^{-1}$ and $526.5 \pm$ $46.6 \mathrm{~kg}-\mathrm{K}_{2} \mathrm{O} \mathrm{ha}{ }^{-1}$.Potassic fertilizer usage was found high while, phosphatic fertilizer application was found least in orchards of both wine and table grape types. Thus, quantities of three major nutrients used among wine and table grape orchards were found in the order: potash $>$ nitrogen $>$ phosphorus fertilizers.

The grape yields are known to respond to nutrient applications (Ganeshmurthy et al., 2011). Achieving/ targeting higher yields with good quality might have forced the farmers to apply higher doses of fertilizer nutrients. This could be the reason for applying large amounts of fertilizers in high yielding table grape types. In terms of its fruit qualities, high sugar contents and less total acidity is achieved by applying high amounts of Kfertilizers during fruit development (Shikamany et al., 1989). Contrastingly, wine grapes are cultivated under nutrient as well as moisture stress conditions to increase total acidity; and enhance tannins and other phenolic compounds (van Leeuwen et al., 2009). These quality parameters are very important to enhance wine quality.

\section{Soil fertility profiles of vineyards}

Soil nutrient availability in a soil is largely determined by soil reaction $(\mathrm{pH})$ and soil organic carbon. Both wine and table rape vineyards recorded moderately alkaline soil reaction with $\mathrm{pH}$ ranging from 7.51 to 8.61. All the vineyard soil samples were found to be non-saline with $\mathrm{EC}_{2.5}$ values ranging from 0.37 to $0.50 \mathrm{dS} \mathrm{m}{ }^{-1}$ and the soil organic-C contents were observed in higher range $(>0.75$ $\%)$. However, the nutrient/ crop management practices for wine/ table grape types did not show any significant influence on the above pH, EC and SOC contents (Table 3/ Figure 3).

The soils of northern Karnataka, belonging to black soils, derived mostly from basalt and gneisses, are formed under semi-arid conditions. Excess applications of manures and fertilizers might have stabilized the soil $\mathrm{pH}$ to around 8.0 (Shranbhupal Reddy et al., 2014; Anita et al., 2018 ; and Shreekanth et $a l .$, 2018). Judicious use of water through drip irrigation systems might have kept low salt contents near the root zone. High soil organic$\mathrm{C}$ contents in vineyards may be attributed to annual and localized applications (in trenches) of organic manure.Similar values of $\mathrm{pH}$ and EC in vineyards were reported earlier by Shreekanth (2016) and Vinod (2016).

In terms of nutrient availability, both wine and table grape orchards recorded nitrogen, 
potassium, sulphur and DTPA-micronutrients in higher availability range (Shivakumar et al., 2016). Available phosphorus in wine grape orchards was the only nutrient observed in medium range while, table grape orchards recorded P-availability in higher range. Comparative analysis of soil fertility of two categories of orchards indicated that the table grape vineyards recorded significantly higher availability of nitrogen, phosphorus, potassium, sulphur, zinc and copper (DTPA$\mathrm{Cu}$ and $\mathrm{Zn}$ ). However, the availability of calcium, magnesium, iron and manganese (DTPA-Fe and Mn) did not differ significantly among two categories of vineyards.

Higher nutrient availability in grape vineyards could be attributed to high nutrient applications by farmers (Anita et al., 2018 ${ }^{\mathrm{b}}$ ). Among two categories, significantly higher nutrient availability in table grape orchards, compared to wine grape orchards, may be attributed to high dose of NPK fertilizer applications. Use of $\mathrm{Zn}$ and $\mathrm{Cu}$ fungicides in table grape vineyards might have caused their build up in soils. Use of high amounts of fertilizer nutrients in horticultural systems especially, in vegetables and fruit crops and corresponding build up of respective nutrients are well documented (Shikamany et al., 1989; Ganeshmurthy et al., 2011; Puneethraj et al., 2013). Higher sulphur contents in grape soils may be due to preference for sulphate of potash instead of muriate of potash as grape is sensitive for chlorides (Shreekanth et al., 2018). Unutilized fertilizers which are immobile in nature are more likely to build up in surface soils (Anita, 2016) and may even induce micronutrient deficiencies due to their antagonistic effects (Shivakumar et al., 2016).

\section{Grape yields and productivity-nutrient ratios}

The fresh grape yields of wine and table grapes varied significantly (Figure 4). The wine grape yields were lesser and it ranged from 10.0 to $13.3 \mathrm{t} \mathrm{ha}^{-1}$ with a mean yield of $12.0 \pm 1.2 \mathrm{t} \mathrm{ha}^{-1}$. In contrast, table grape yields were higher ranging from 21.3 to $27.0 \mathrm{t} \mathrm{ha}^{-1}$ and mean yield $24.0 \pm 1.50 \mathrm{t} \mathrm{ha}^{-1}$. Productivity of grapes per unit of applied N, P and K nutrients were derived using total individual nutrients added and the corresponding yields.

Table.1 General nutrient management practices adopted for wine and table grape cultivation in northern dry zone of Karnataka

\begin{tabular}{|c|c|c|c|c|}
\hline Grape type & $\begin{array}{c}\text { Major varieties of the } \\
\text { region }\end{array}$ & Management & Recommended & $\begin{array}{c}\text { Farmer's } \\
\text { practice }\end{array}$ \\
\hline \multirow[t]{5}{*}{ Wine } & \multirow{5}{*}{$\begin{array}{l}\text { Souvignon Blanc, } \\
\text { Cabernet, Tempranillo, } \\
\text { Shiraj and Medika }\end{array}$} & Spacing (ft) & $8 \times 6$ & $\begin{array}{l}10 \times 5 \\
12 \times 6\end{array}$ \\
\hline & & $\mathrm{N}\left(\mathrm{kg} \mathrm{ha}^{-1}\right)$ & 100 & $375-525$ \\
\hline & & $\mathrm{P}_{2} \mathrm{O}_{5}\left(\mathrm{~kg} \mathrm{ha}^{-1}\right)$ & 165 & $335-543$ \\
\hline & & $\mathrm{K}_{2} \mathrm{O}\left(\mathrm{kg} \mathrm{ha}^{-1}\right)$ & 335 & $450-625$ \\
\hline & & FYM $\left(\mathrm{t} \mathrm{ha}^{-1}\right)$ & 10 & $10-15$ \\
\hline \multirow[t]{5}{*}{ Table } & \multirow{5}{*}{$\begin{array}{l}\text { Thompson Seedless } \\
\text { Sonaka,ManikChaman, } \\
\text { Manjre Naveen, } \\
\text { Sharad Seedless, } \\
\text { Krishna Sharad, } \\
\text { Fantasy Seedless and } \\
\text { Red Globe }\end{array}$} & Spacing (ft) & $8 \times 6$ & $\begin{array}{l}10 \times 5 \\
12 \times 6\end{array}$ \\
\hline & & $\mathrm{N}\left(\mathrm{kg} \mathrm{ha}^{-1}\right)$ & 300 & $365-715$ \\
\hline & & $\mathrm{P}_{2} \mathrm{O}_{5}\left(\mathrm{~kg} \mathrm{ha}^{-1}\right)$ & 500 & $325-640$ \\
\hline & & $\mathrm{K}_{2} \mathrm{O}\left(\mathrm{kg} \mathrm{ha}^{-1}\right)$ & 1000 & $525-1280$ \\
\hline & & FYM $\left(\mathrm{t} \mathrm{ha}^{-1}\right)$ & 25 & $14-28$ \\
\hline
\end{tabular}


Table.2 Cost- benefit analysis of table and wine grape cultivation (per ha basis) in northern dry zone of Karnataka

\begin{tabular}{|c|c|c|c|c|}
\hline SI.No & Particulars & Unit & Wine Grapes & Table Grapes \\
\hline \multirow[t]{3}{*}{1} & $\begin{array}{l}\text { Cost of cultivation excluding } \\
\text { fertiliser nutrient cost }\end{array}$ & \multirow[t]{3}{*}{ Rs. } & $3,00,615$ & $3,37,622$ \\
\hline & Cost of fertilizer nutrient & & 31,549 & 42,055 \\
\hline & Total cost of cultivation & & $3,32,164$ & $3,79,678$ \\
\hline 2 & Yield & Kgs & 12,000 & 23,952 \\
\hline 3 & Rate & $\mathrm{Rs} / \mathrm{Kg}$ & 40 & 25 \\
\hline 4 & Gross Returns & Rs. & $4,80,000$ & $5,98,815$ \\
\hline 5 & Net Returns & Rs. & $1,47,836$ & $2,19,137$ \\
\hline 6 & $\mathrm{~B}-\mathrm{C}$ ratio & & 1.44 & 1.57 \\
\hline
\end{tabular}

Fig.1 Amounts of major nutrients used in grape vineyards

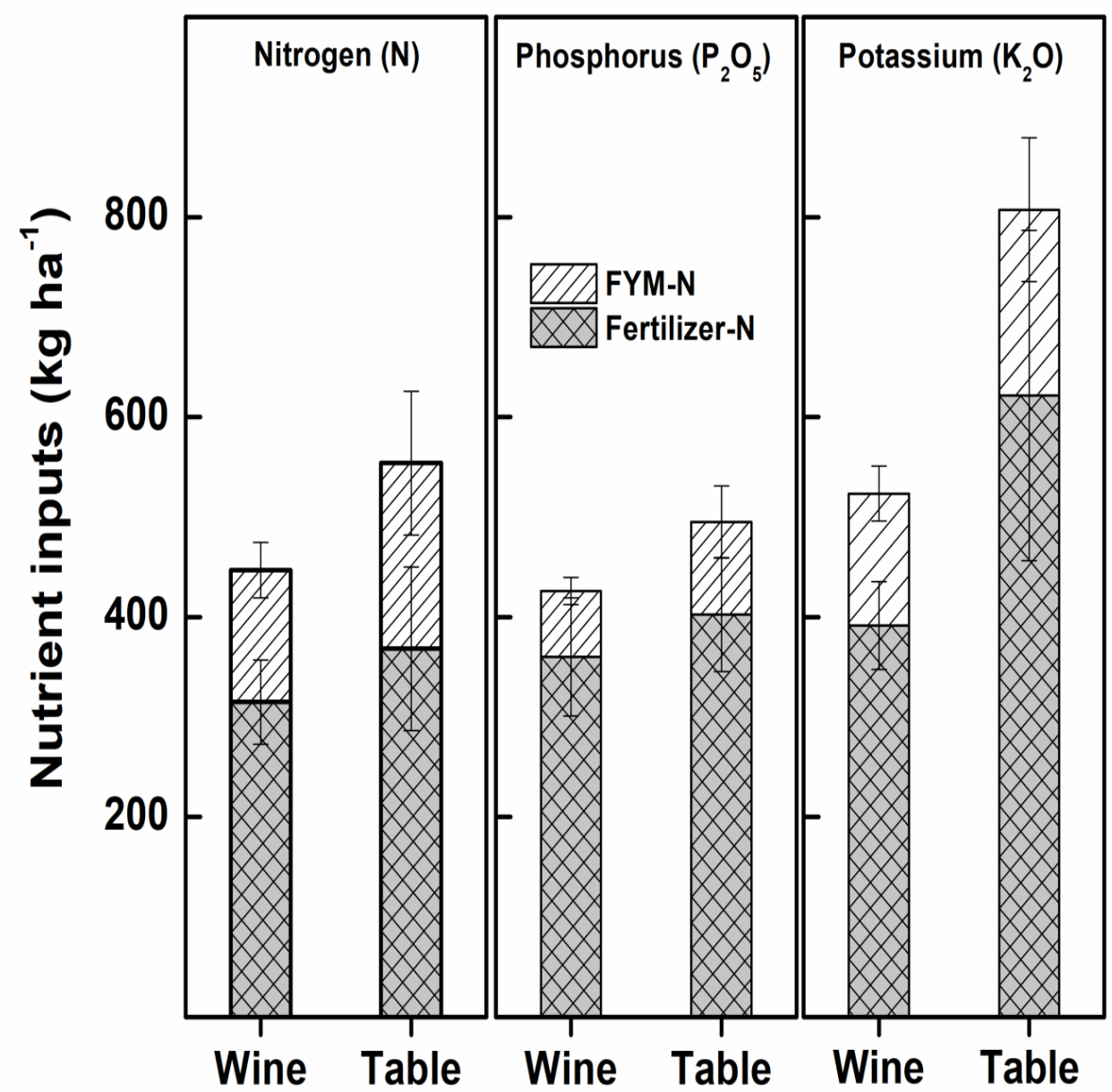

(Data used with permission from Contemporary Research Journal - Anita Kondi et al., 2018a) 
Fig.2 Available major nutrient status among grape vineyards
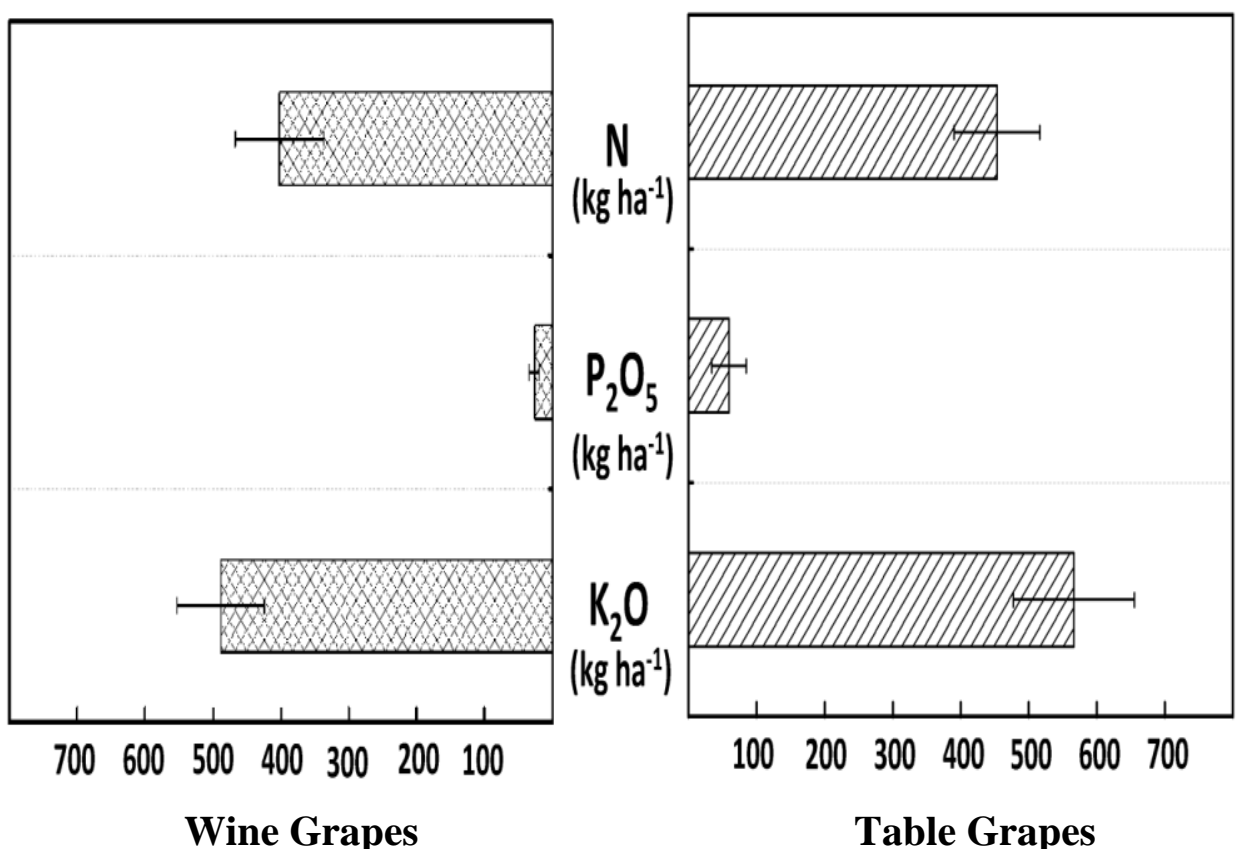

Fig.3 Grape yields of different grape vine yards

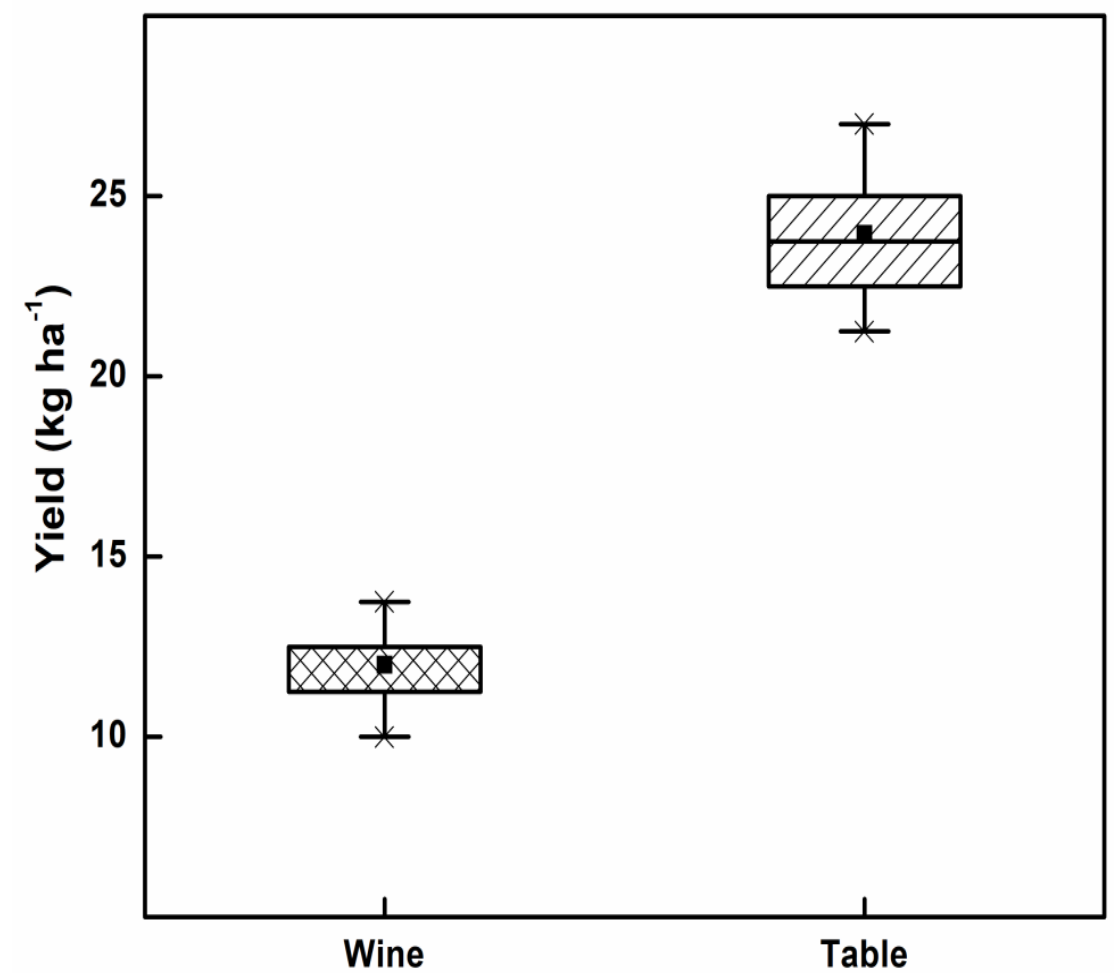

(Data used with permission from Contemporary Research India; Anita Kondi et al., 2018a) 
Fig.4 Nutrient use efficiencies in grape vineyards

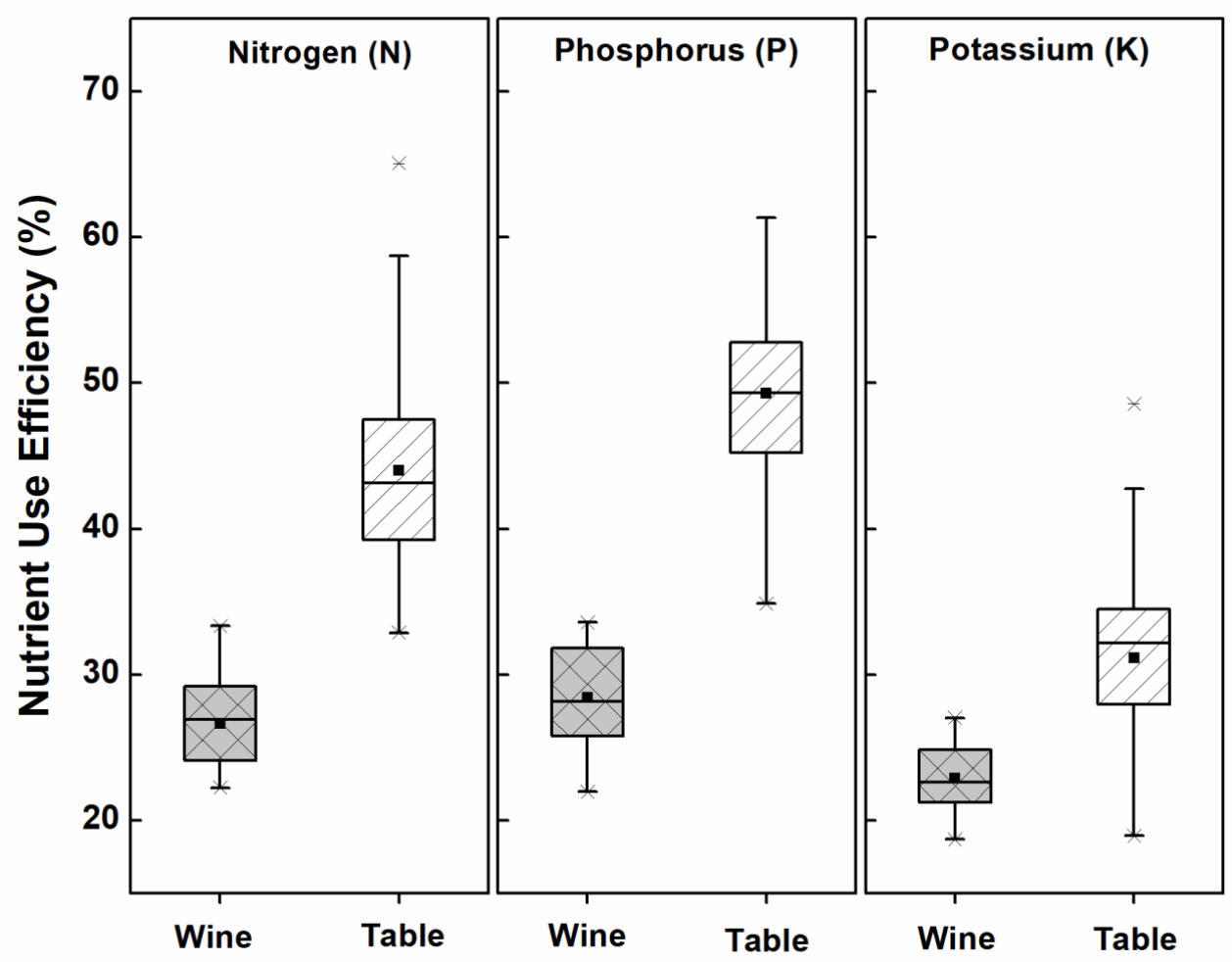

It was interesting to observe that the productivity -nutrient ratios of table grapes were found to be significantly higher while, wine grape orchards recorded lower productivity-nutrient ratios (Figure 4). The grape yields per $\mathrm{kg}$ of nitrogen were found to be $44.0 \pm 6.4 \mathrm{~kg}$ in table grape types compared to lower values of $26.6 \pm 3.0 \mathrm{~kg}$ in wine grapes. Similarly, the productivity per $\mathrm{kg}$ of phosphorus was found to be $49.3 \pm 7.2$ and $28.4 \pm 3.7 \mathrm{kgs}$ in table and wine grape vineyards respectively. Interestingly, the productivity per $\mathrm{kg}$ of potassium nutrient added was found substantially lower compared to other two nutrients $(31.2 \pm 6.6$ and $22.9 \pm 2.4 \mathrm{kgs}$ in table and wine grape orchards respectively).

Higher yields in table grape types and contrasting lower yields in wine grape types may be attributed to their inherent genetic nature of the varieties/genotypes (Patrice et al., 2006). Table grape types are known to be highly nutrient responsive compared to wine type and thus, higher yields may be mostly due to higher nutrient applications (Anita et al., 2018 and Vinod Naraboli et al., 2017). Response of the crop to nutrient applications also indicated higher productivity per $\mathrm{kg}$ of nutrients in table grape types.

\section{Cost-benefit analysis}

The information on cost of cultivation, nutrient input cost, gross and net returns and cost-benefit ratios of wine and table grapes are given in Table 2. The cost of cultivation of wine and table grapes was found to be Rs. 3,00,615/- and Rs. 3,37,622/- respectively. The corresponding nutrient input costs were found to be Rs. 31,549/- and Rs. 42,055/-. Based on the present market price of Rs. 40 per $\mathrm{kg}$ of wine grape and Rs. 25 per $\mathrm{kg}$ of table grape (Jan, 2019), the gross returns were 
found to be Rs. 4,80,000/- and Rs. 5,98,815/-. The respective net returns were estimated to be Rs. 1,47,836/- and Rs. 2,19,137/-. Thus, the worked out cost-benefit ratio were found to be 1.44 and 1.57 respectively for wine and table grapes. Thus, it clearly suggests that the cultivation of grape is a lucrative option for the farmers.

Considering the economic importance of the table grape types, breeders have evolved / developed several nutrient responsive genotypes. In contrast, the wine industry demands for grapes with high tartaric acid and flavonoids and low sugar contents to produce best quality wines. The fruits attain these qualities when they are grown under water stress conditions resulting in lesser yields (Van leeuwen et al., 2009). This could be the reason for observing lower nutrient productivity values in wine grapes indicating scope for reducing the present levels of nutrient application.

\section{References}

Anita E. Kondi, 2016. Nutrient management practices in grape orchards of Bagalkot and Jamakhandi talukas: effects on soil fertility, petiole nutrient contents and yields. M.sc Thesis, University of Horticultural Science, Bagalkot, India.

Anita, E.K., Prashant, C.T., Champa, B.V., Shivanna, M and Nagaraja, M.S., 2018. Secondary and micronutrient status in soils of wine and table type grape orchards of northern Karnataka. International Journal of Chemical Studies, 6(3): 2335-2358.

Aradhya, M.K., Dangl, G.S., Prins, B.H., Boursiquot, J.M., Walker, M.A., Meredith, C.A. and Simon, C.J., 2003. Genetic structure and differentiation in cultivated grape, Vitis vinifera L. Genetics Research Cambridge, 81: 179-192.
Ganeshamurthy, A. N., Satisha, G. C., Patil, P., 2011, Potassium nutrition on yield and quality of fruit crops with special emphasis on banana and grapes. Karnataka Journal of Agriculture Science., 24 (1): 29-38.

McGovern P.E. 2003. Ancient Wine. The Search for the Origins of Viniculture. Princeton University Press, Princeton, NJ.

Patrice, Thierry Lacombe and Mark R. Thomas., 2006, Historical origins and genetic diversity of wine grapes. Trends in Genetics, 22(9): 511-512.

Punith Raj, T.S., Nagaraja, M.S., Prabhudev Dhumgond, Sharanbhoopal Reddy, Shivakumar, K.M., 2013. Variation in tomato productivity in hassan district due to nutrient application. Bioinfolet, 10 (3B): 962-964.

Sharan Bhoopal Reddy, Nagaraja, M.S., Punith Raj, T.S., Prabhudev Dhumgond and Vignesh, N.S., 2012. Influence of land use system and its management on fertility status of soils under varied climates, Research Journal of Agricultural Sciences, 3(5): 1113-1115.

Sharanbhoopal Reddy, Nagaraja, M.S., Punith Raj, T.S., Police Patil A.S. and Prabhudev Dhumgond, 2014. Elemental analysis, e4/e6 ratio and total acidity of soil humic and fulvic acids from different land use systems, Annals of Plant and Soil Research, 16(2): 89-92.

Shikhamany, S. D., Chittiraichelavan, R. and Chada, K. L., 1989, Effect of varying levels of nitrogen and potash on petiole nutrient contents in Thompson Seedless grape (Vitis vinifera L.), Indian Journal of Horticulture, 45: 180-188.

Shivakumar, K.M. and Nagaraja, M.S., 2016. Micronutrient status in soils of Chilli grown areas of UKP command areas of Karnataka. An Asian Journal of Soil Science, 11: 337-340.

Shreekanth Shivannanavar., 2016. Effect of 
nutrient management practices in grape orchards of vijayapura on soil properties, petiole nutrient contents and grape yields. M.sc Thesis, University of Horticultural Science, Bagalkot, India.

Shreekanth. S, E.K. Anita, M.V. Rekha, B.V. Champa and M.S. Nagaraja, 2018. Secondary and Micronutrient Status in Soils of Grape Orchards of Vijayapura Taluka in Northern Karnataka, India., International Journal of Current Microbiology and Applied Sciences. 7(5): 1393-1401.

Van leeuwen, O Tregoat, X., Chone B. Bois, D. Pernet and J.P. Gaudillere, 2009, Vine water status is a key factor in grape ripening and vintage quality foe vineyard management purpose? Journal of International Science Vitis vinifera, 43:121-134.

Vinod Naraboli, 2016. Effect of nutrient management practices in grape orchards of jamakhandi on soil properties, petiole nutrient contents and grape yields. M.sc Thesis, University of Horticultural Science, Bagalkot, India.

Vinod, C.N., Greeshma Reddy, B.C., Shivannanavar, S., Shankar Meti,
Ashok S. Alur and Nagaraja, M.S., 2017. Optimization of soil and plant indices for managing potassium nutrition in grape orchards of northern Karnataka. The Bioscan, 12: 301-304.

Vinod, C.N., Srikanth, S., Ajay K. Bhardwaj, Shankar Meti, Ashok S. Alur and Nagaraja, M.S., 2019. Simple estimates for optimization of potassium nutrition in vineyards. Current Science, 116 (1): 30-32.

Yogeeshappa, H., 2007, Yield and quality of grapes (cv. Thompson Seedless) in relation to soil fertility status of vineyards in Bijapur taluk of Karnataka. M.Sc Thesis. Agric. Sci., Dharwad (India).

Zeo Migicovsky., Janson Sawler., Kyle MGardner, Mallikarjuna K Aradya, Bernard H Prins,, Heidi R Schwaninger, Carlos D Bustamante, Edward S Buckler, Gan-Yuan Zhong, Patrick J Brown and Sean Myles, 2017, Pattern of genomic and phenomic diversity in wine and table grapes. Horticulture Research, 4: Article no. 17035 (DOI:10.1038/hortres.2017.35).

\section{How to cite this article:}

Anita E. Kondi, Prashant C. Tevaratti, Champa B.V. Kulapathi Hipparagi and Shripad Vishweshwar. 2019. Comparison of Nutrient Use Efficiencies and Cost Benefit Ratios in Wine vs. Table Grape Vineyards in Northern Dry Zones of Karnataka, India. Int.J.Curr.Microbiol.App.Sci. 8(03): 1096-1104. doi: https://doi.org/10.20546/ijcmas.2019.803.132 